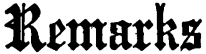

Ox

\section{SOME POINTS IN THE HISTORY OF ANTISEPTIC SURGERY.}

\section{BY LORD LISTER, F.R.S.}

THrs following unfinished letter to Sir Hector Cameron was written early in 1906, before the delivery of his Lectares on the Fivolution of Wound Trestment, bat never sent to him. I have been assured that it would have suffiolent interest for some resders to warrant its publication.

\section{Mr danar Oammbon,}

It seems superfinous for me to write angthing to you with reference to your coming lectures. But perhap: In what I shall say, there may be here and there points which may interest you.

In treating surglcal cases antiseptically I always endeavoured to avoid the direct action of the antiseptic substance upon the tissues, 80 far as was consistent in the exlating state of knowledge with attaining the essential object of preventing the development of injurlous miarobes in the part concerned.

In compound fracture; to which, in 1865, I first put in practice the antiseptlc principle, I applied undilated carbolc acld treely to the injured part, in order to destroy the septlc microbes already present in 1t; regarding the caugtlo setion whlch I knew must occur, as a matter of small moment compared with the tremendous evil which It was sought to avold. But when this had once been done, no further direct action of the antiseptic upon the tissues occurred. The carbollc acld formed with the blood a dense chemical compound which, together with some lavers of lint steeped in the acld, prodnced a crust that adhered firmly to the wound and the adjacent part of the skin. This crust was left in place till all danger was over, Its surface belng painted from time to time with the acld, to guard againgt the penetration of septlc change Into Its substance. Mesn while In the undisturbed wound the beantiful result occurred that the material of the crust within it, and the portlong of tigene which had been destroyed by the canstic, were replaced by living tissue commed. at their expense.

That dead tissue, when protected from external Influences, was so dituposed of, was a most Important truth new to: pathology: and it afterwards anggested the Idea of the catgut ligature.

I do not remember whether $704 \mathrm{saw}$ the case that led me to apply the antiseptic princlple to abscess. The patient was a woman above the midale period of life with Immber abscess. Tanght by the disestrous results thet sooner or later followed the evacuation of such abscegses, whether by valvular opening or by cannula and trocar, I left the case undisturbed; till one day, on looking at it I found thet nothing but epldermis seemed to intervene between the pus and the external world, so that if leit for another:day, it would in all probabillty burst.

I therefore resolved to open it and apply a dressing which should Imitate, as much as clrcumstances permitted, that which we used in compound fractures. The pus which escaped on Incision was as thick as any I ever saw. Mixing some of It with undiluted carbolic acld, I applled some lapers of lint sosked with the mixture to the wound and surrounding skin and covered them with a plece of thin block tin moulded to proper shape, such as we used for covering the crust in componnd frecture This metal covering, which prevented loss of carbollc acld by evaporation and sosking Into surrounding dressings. was. fixed by strapplng, and a tolded towel was bandaged over it to absorb disoharge.

Next day, on changing the dressing, I was greatly astonished to see nothing escape from the incision except a drop or two of clear serum. What was now to be done? I had no longer any pus to mix with the carbollc acld. But it occurred to me that I might make a satisfactory cruat by mixing carbollc acld with glazier's putty. Accordingly I sent to the dtepensary for some whiting and bolled.linseed oll, and making a solution of one part of carbollc acid In four of the oll, rubbed it up wlth whiting in a mortar, thus making a carbolic putty. This I spread on a plece of block tin and appled it as I had done the firgt dressing. There never was ang forther dischange of pus; the serous ooring diminished rapldly. and before long healing was complete.

In that case, as there was no spinal carvature, I conld not be sure that the abscess was. connected with the vertebrae. But simllar results afterwards followed the same treatment where disoharge of bone sharred that anch connexion exlsted and also In suppuration of the hlp.jolnt, whether attended with shortening of the limb or not, scrupulous care belng taken to keep the affected part completely at rest. The time required for final closing of the sinus was, however, generally much longer than in the first case.

Precisely the same besntlinl result, so entirely novel and so full of deep interest both for pathology and prectice, was seen when acute abscesses were treated in the name way; the only difference belng that in the acute cases the serous oozing which followed evacuation of the pus came much more rapid]y to a conclusion.

In order to ensure freedom of escape for the sexum, a narrow strip of lint sosked with a solution of carbolic acid In four parts of olive oil was inserted in the Incision. But the antiseptic substance was never from first to last applled to the cavity of the abscess, as such treatment could only have been productive of needless irritation.

I contlnued to use a strip of lint as a drain for abont five years with perfectly satisfactory reaults. But in 1871 having opened a very deeply-seated acute abscess in the axills, I found to my surprise, on changing the dressins next day, that the withdrawal of the lint was followed by escape of thick pus like the original contents.

It occurred to me that in that deep and narrow incision. the lint, Instead of serving as a drain, might have acted like a plug, and so reproduced the conditions present before evacuation. Taking a piece of the India-rubber tublng of a Rlchardson's spray producer that I had used for local anaesthesis at the operation, I cut holes In It and attached knotted silk threads to one end, so improvlsing a drainage tube. This I put to steep for the night in a strong watery solution of carbollc acid, and Introduced It In place of the lint on changing the dressing next morning. The withdrawal of the lint had been followed by discharge of thick pus as before, but next marning I was rejolced to find nothing escape unless it were a drop or so of cleari sernm. This rapidly diminished, and within a week of the opening of the abscess I was able to take leave of my patient, the discharge from the abscess cavity having entirely ceased.

After that case. I nsed drainage tubes as a rule In the treatment of abscess. But it is well to remember that if anch a tube shonld not be at hand, a narrow strip of lint, sterllized of course with some trustworthy antiseptic solution, will in almost every case answer the purpose. equally well.

The crude carbollc acld which, under the name of German creasote, was supplled to me by my.colleague Dr. Anderson, Prolessor of Chemistry in the Universiby of Glasgow, was a brown liquid which had been adulterated with water, and this lay on the top as a clear. layer, destitute of any flevour of carbollc acid. This led me in my first paper on compound Iracture to speak of carbollc acid as absolutely insoluble in water. But when it was alterwards produced in a comparatively pure condition in colourless crystals, it proved to be capable of belng taken up by water, though twenty parts were required for the purpose. The watery solution, however, though weak numerlcally, showed itsell to be exceedingly potent as an antiseptlc. Having applied it to a foul sore in the palm of the hand, I found, on changing the dressing next day. that all putrefactive odour had disappeased.

This ensbled me to use carbollo acid for washing wounds after operations and so to ertend the appllas: thon of the antigeptlc princlple to surgery: In general. In the state of knowledge at that eanly perlod it sepmed imperative to apply a powerful germlolde to the wound before closing it. To use undlluted carbollo acid for operation wounds, as 1 had done in composind fracture, was out of the question; and carbollc oll, though I did Indeed try It, was Ill adapted for the purpose. But the watery solution could be satiafactorlly used not only for washing the wound, but also for purifylng the surrounding skin, the hands of the operator and the instruments.

The entire absence of carbollc acid in the lazer of water on the "German creasote" with which I made my first attempts with compound iractures Indicates that there 
were present in the crude product substances for which the acld had incomparably greater attraction than it had for water. When purlfied from these substances, it is indeed soluble in water, but only in small amount; and being so feebly held by water, it is free, when in watery solution, to act upon other matters for whlch it has stronger attraction. Thus was explained the remarkable germicldal energy of a lotion containing only a twentleth part of carbolic acid, as lllustrated by the foul sore in the hand before relerred to.

With linseed oll, on the other hand, the acid conld be mired in any proportion, and belng firmly held by the oll, it was mild in action, though present in the large proportion of 1 to 4, as used in the carbolic putty. The 1 to 4 carbolic oil is bland when applied to the tip of the tongue, whereas the 1 to 20 watery solution is intolerably pungent.

The acld in the watery solution, while potent in action when applied, is soon dissipated, whereas it is slow in leaving the oil. Hence the watery solution, powerial but transient in operation, was admirably adapted for application to a cut surface as a detergent, while the carbolic putty, bland in action and serving long as a store of the antiseptic, could be used with good effect not only for abscesses, but also as an external dressing for operation wounds; and for that purpose I long employed it. The putty. was used in a layer spread on calico, freely overlapplng the skin around the wound, and covered with a tolded cloth to absorb the serum that flowed from beneath its edges. Although this mode of dressing gave place in time to others which were more convenlent, the change effected under its use at that early. perlod was of the most striking character : healing without suppuration, paln or fever, instead of belng the rare exception; became the rule, and operations were safely performed which had previously been utterly prohibited on account of the danger that attended them; while pyaemla and hospital gangrene, which had betore been disastrously rife, were banished from my wards.

Epldermis is a substance for which carbolic acld bas special attraction; and this, coupled with the facllity with which the acid blends with olly matters, renders it pecullarly fitted for purifying the skin about the sest of operation and the eurgeon's hands. Another property which aids its actlon as a detergent, is its great penetrating power, not limited by the products of its chemical action upon organic substances.

I used the 1 to 20 watery solution for rendering the patient's skin and the hands of myself. and my asslstants aseptic throughout the forty years durlng which I practised on the antiseptic princlple, and I never had any reason to doubt its efficacy. No:Iong time Is required for 1 ts action. In my private practice the purification of the skin was as a rule not began till I entered the patient's room to perform the operation. The part concerned was then thoroughly washed with the 1 to 20 carbollc solution, and was kept covered with lint soaked with the same lotion while the instruments were belng attended to and the anaesthetlc administered; the whole process occupplng only about a quarter of an hour. Yet experlence showed that thls briel period was. anfficient.

It may perhaps be argued that under the carbollc putty or any other dressing contalning carbolic acid, that volatile agent was perpetually acting on the skin and may have made up for deficiencles in the original purification. Bat during several years belore I gave up practlce, the dressings did not owe their virtues to any volatile antiseptic.

I may mention in lllustration one of my latest operations. The patlent was a lady advanced In years, with a large ventral hernia below the umbilicus. It was producing serlous symptoms; and attempts to reduce it having falled, her condition had become exceedingly grave. I only began to disinfect the skin when she was already partly under the influence of the anaesthetlc. The umbllicus contsined some drops of opaque llquid of a highly offensive charaster. I cleansed its folds carelully with the 1 to 20 carbollc +solution : and washed the -skln over and around the sac with the same lotion. The sac was opened by a median incision, the upper end of which extended to the umbllicus. Into further detalls of the operation I need not enter. On changing the dressing (of cranide ganze) it appeared that, in her frall condition, the margins of the skin at the upper end of the incision had lost their vitality over an extent of about $\frac{1}{2}$ in. in length and ${ }_{1}^{1} 0$ In. In breadth at each side. I afterwards left the dresaing unchanged for several days, when I found that the sloughs, the upper ends of which encrosched on the umbllicus, so foul before the operation; had been replaced by new living tissue, and complete clcatrization had occurred without the formation of a particle of pus.

I cannot bat think it a happy clrcumstance that the substance which I employed first in endeavouring to apply the antiseptlc princlple should have been so admirably adapted for detergent purposes. And it has grieved me to learn that many surgeons have been led to substitate needlessly protiracted and complicated measures for means. so simple and efficient,*

As an Instance of trouble misapplied in this matter, may be mentloned prellminary washing with soap and water. If carbolic acla is the disinfectant used, such washing lo not only wholly unnecessary, but is, I belleve, positively Injurious; ss it must tend to check the penetration of the germicide into the substance of the epldermis, by satarating it with water for whlch carbollc acid has so little affinity. That this practice is superfluous 1s; I venture to think, proved by my experlence, as I never in any case. adopted it.

The Incomparably greater attraction of carbollc acld for epidermis than for water was strikingly llustrated by an. experiment not hitherto published.

Here my letter was broken off, in consequence of other engagements. Bat I afterwards wrote to SIr Hector Cameron what I had Intended to say on this subject and he was good enough to incorporate my remarks in his second leoture (see BRITISH MEDICAL JOURNAL, Aprll 6th, 1907, p. 799).

\section{CYSTIC TUMOUR OF THE SUPRARENAL BODY SUCCESSFULLY REMOVED BY OPERATION,}

WITH NOTHS ON CASHS PREVIOUSLY PUBLISHRD. $†$

BY ALBAN H. G. DORAN, F.R.C.S.,

SENIOR SURGEON, SAMARITAN FREE HOSPITAL.

\section{INTRODUOTORY RHMARKS.}

MANY observations have recently been publlshed about the pathology, diagnosis, and treatment of tumours of the suprarenal body and of new growths developing in other organs from "rests," as they are termed, of adrenal tissue. An Instance of the latter type of tumour was reported by myself last year. In the autumn of 1906 . I removed a kldney subject to " hypernephroma," the patient surviving the operation for three months, bat there were secondary adrenal deposits, one appearing as a. vaginal polypus. Eleven months later I removed a tumour situated in the left lumbar region. It proved to be a c7st ol the suprarenal body itself, unllocular and full of a bloody fluid. : Henschen would rank it as a struma suprarenalis. oystioa haemorrhagica. I will now relate my case and afterwards make some mention of previously reported Instances of cystic tumiour of the suprarenal body large enough to be of clinical and surgical interest.

\section{THR CAsF.}

C. L., aged 62, was admitted Into my wards in the Samaritan Free Hospital on Ootober 1st, 1907, on account of an abdominal. swelling and pain

She had been married for thirty years, and had borne nine ohlldren, the last confinement occurring elghteen years before admission. There had been no abortions. All the patient's labours were normal except the last, when the forceps was. applied. She had never soffered from any puerperal com. pilostion, but enteroptosis developed during the later pregnencles.

In 1897 she was laid up with Influenza, whloh left her very weak and liable to bronchitis ; at the same time she suffered from frequent attacks of pain after food and romiting. The influenzs troubled her again several times; on the last occasion, which was in 1904, she became deaf in the left ear.

History of the Present Illness.-The dyspeptio attacks, which had never ceased entirely, became severe last summar

* The fear sometimes expressed of poisonous effects from carbolic acid, as used in antiseptic surgery, is, so far as my experience goes,

t Read at a meeting of th Medicine, Juve 16th. 1908 . I Malignant Vaginal Polypus, secondary to an Adrenal Tumour of Obst. and Gyn. Trans. Obst. Soc, vol. xlix, 1\&07, p. 182, and Journ. of and Gyn. of Brit. Emp., vol. xi (June, 1207), p. 449. 